\title{
An Economical Review of Dehydrated Onion Firm of Mahuva Taluka of Bhavnagar District, Gujarat
}

\author{
Bansri Pandya, Dr. Waheeda Thomas \\ ${ }^{1}$ Ph.D. Student, ${ }^{2}$ Principal of SEMCOM College \\ ${ }^{1}$ kartikbhatt1@gmail.com ${ }^{2}$ waheedathomas@gmail.com
}

\begin{abstract}
:
The fruits and vegetables processing industries have tremendous potentials in creating income and employment for rural labour-force. This study is concerned with the problems and prospects of the cluster of onion dehydration enterprises located in Mahuva taluka Bhavnagar district of Gujarat state in India. This paper is regarding contribution of onion dehydration firm in Indian Economy. We wish to discuss about types of different product produced in large amount by onion dehydration firm, on the basis of primary data.
\end{abstract}

Keywords: Onion dehydration firm; competitiveness, production, establishment of firm.

\section{Introduction:}

Present study is based on the dehydrate onion firm of Mahuva taluka of Bhavnagar district, Gujarat, India. The study is based on the primary data collected from the questionnaire base and some information was collected in the form of Secondary data from the web-site, newspaper and articles. First we gathered information about establishment of dehydration firms and latter we collect information of production produced by them. They produced mainly five items namely Kibbled, Chops, Minced, Granula and Powder. Detail tables and its graphical presentation are as follows. First four products are main products of dehydrate onion and there is no waste remain because after all the product produced remaining part of dehydrate onion converted into powder form which is also very popular in international market.

\section{Literature Review:}

1. Angles, S., Sundar, A., Chinnadurai, M. (2011), "Impact of Globalization on Production and Export of Turmeric in India - An Economic Analysis" studied for the period 1974-75 to 2007-08, they studied that, India is a major supplier of turmeric to the world with more than 60 per cent share in turmeric trade. The growth in production and export of turmeric has been reported significant, because of the high demand coupled with inflation. Instability index has been worked for the production and export for pre-liberalization and postliberalization periods.Instability has been observed high for production, export and prices of domestic and international markets and domesticand international prices have shown high integration. The countries such as USA and Japan have not been the stable importers of Indian turmeric. 
2. Serrano, Raúl., and Pinilla, Vicente (2010), "International Diversification And Performance In Agri-Food Firms" for time interval 1970-2012.We have studied the influence of the degree of internationalization with a measure that combines export intensity and regional diversification. According to author the internationalization process of a Spanish food firm is more regional than global.The author has conclusively confirmed the existence of a horizontal S-shaped relationship between international diversification and performance for Spanish food exporters.

On the basis of the reviewed literature the present study focused on following objectives.

- To do detailed economic analysis of dehydrate onion firms situated in Mahuva Taluka of Bhavnagar district.

- To know the Owner's behaviour about investment and economic gain who are associated with dehydrate onion firms.

- To determine the effect on Indian Economic by earning international wealth.

In this research paper we discuss about primary data and its outcomes. As per prior information there are total 104 Firms. We gathered their basic information like year of established and whether it is registered with DSI or not. To easily understand we construct following table of general information of Dehydration Firms of Onion.

Table 1: General Information of Dehydration Firm

\begin{tabular}{|c|c|c|c|c|}
\hline $\begin{array}{c}\text { Sr. } \\
\text { No }\end{array}$ & $\begin{array}{c}\text { Year of } \\
\text { Establishment }\end{array}$ & $\begin{array}{c}\text { No. Of Onion } \\
\text { Dehydration Firm }\end{array}$ & $\begin{array}{c}\text { Percentage } \\
(\boldsymbol{\%})\end{array}$ & $\begin{array}{c}\text { Name Of Reg. } \\
\text { Office }\end{array}$ \\
\hline 1 & 1980 to 85 & 5 & 4.81 & DSI \\
\hline 2 & 1985 to 90 & 10 & 9.62 & DSI \\
\hline 3 & 1990 to 95 & 8 & 7.69 & DSI \\
\hline 4 & 1995 to 2000 & 12 & 11.54 & DSI \\
\hline 5 & 2000 to 05 & 14 & 13.46 & DSI \\
\hline 6 & 2005 to 10 & 12 & 11.54 & DSI \\
\hline 7 & 2010 to 15 & 28 & 26.92 & DSI \\
\hline 8 & 2015 to 20 & 104 & 100 & DSI \\
\hline Total & & 15 & & \\
\hline Source: Author's calculation based on primary data \\
\hline
\end{tabular}

From the following figure 1 we can easily shows the trend that onion dehydration firms are increased as it is fast growing industries. Even it plays of wide role to develop Indian Economy. Mahuva, home to almost $80 \%$ of onion dehydration units, finds itself catering more and more to domestic needs, as opposed to export demand. A surge of ready-to-eat and fast foods is expected to take domestic consumption from $25 \%$ of Mahuva's dehydrated product to a $100 \%$ very soon. 
Figure 1: Graphical Presentation of General Information of Dehydration Firm

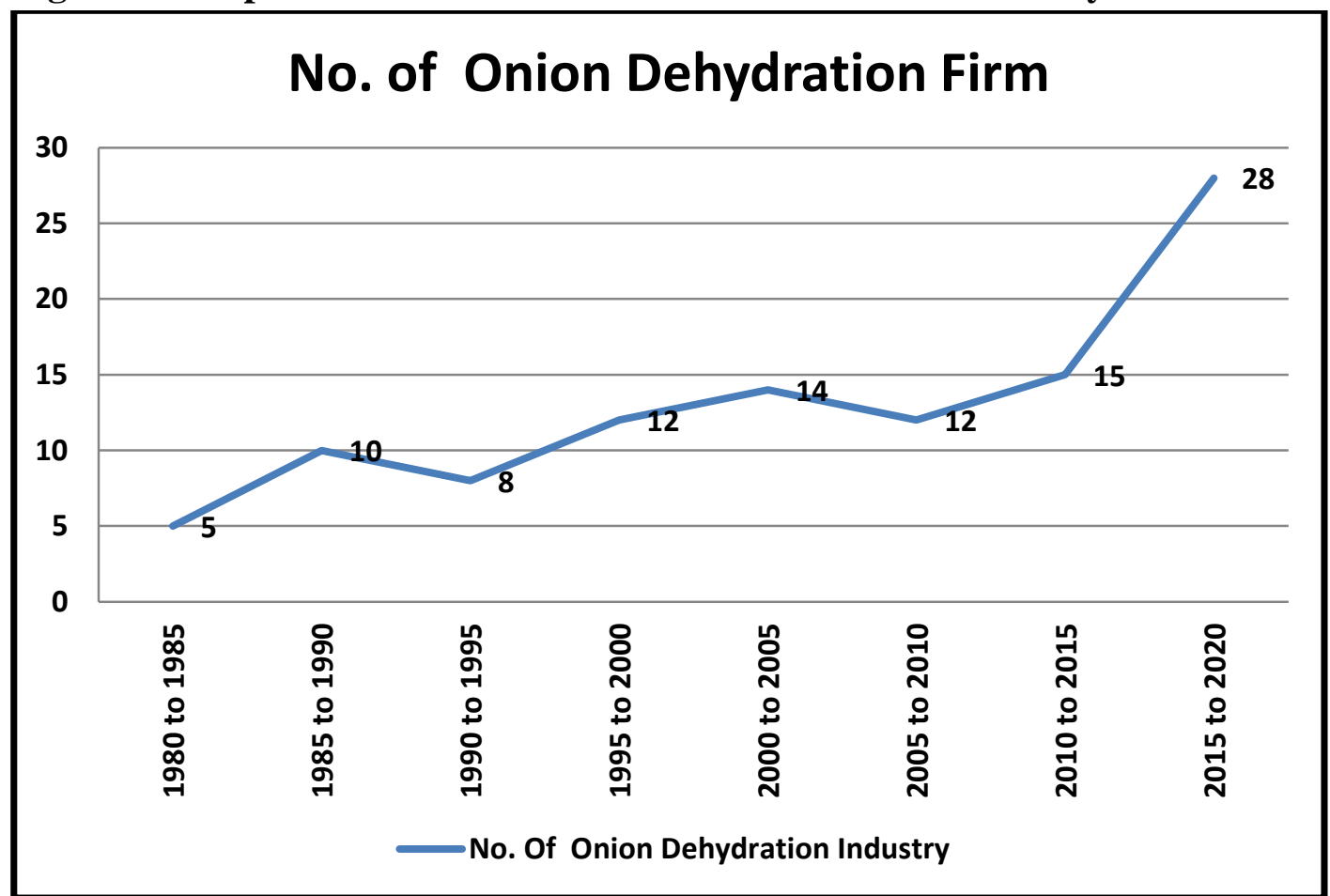

\begin{tabular}{|l|l|l|}
\hline Product & Product Image and Description \\
\hline Kibbled & $\begin{array}{l}\text { Kibbled is widely used in specialty ethnic food preparations, dry soups, } \\
\text { mixes, canned/dried/frozen vegetable mixes, dry casserole mixes, and stuffing } \\
\text { mixes. It is also known as Dehydrated Onion Flakes. }\end{array}$ \\
\hline Chops & $\begin{array}{l}\text { Dehydrated onion chops are highly used for preparing ethnic food, canned \& } \\
\text { frozen vegetable mixes, dry casserole mixes and stuffing mixes. }\end{array}$ \\
\hline
\end{tabular}




\begin{tabular}{|c|c|}
\hline Minced & $\begin{array}{l}\text { Dried onion minced works well in any kind of salad. It is used into the } \\
\text { dressing for leafy greens, beans or grains. Or toss it into chicken, tuna or } \\
\text { potato salad when you add the mayonnaise or a creamy dressing. }\end{array}$ \\
\hline Granula & $\begin{array}{l}\text { The Dehydrated onion granule is a finer version of onion flakes, mainly used } \\
\text { to dress or garnish the salads and prepared dishes to add the sweetish and } \\
\text { nutty onion flavor. The onion granules are mostly utilized for a heightened } \\
\text { taste of fruit salads, snacks, momos, and hot fast foods. It is also applied to } \\
\text { baked or roasted food items and spicy soups for a pungent aromatic flavor of } \\
\text { onion. }\end{array}$ \\
\hline Powder & $\begin{array}{l}\text { Dehydrated Onion Powder is a very common component of spices mix all } \\
\text { over the world. }\end{array}$ \\
\hline
\end{tabular}

We construct the following tables of various items produced from Onion by dehydrating it. We consider main five items produced namely Kibbled, Chops, Minced, Granula and Powder which is described earlier. We construct five tables' year wise and we distribute all 50 Onion dehydration Firms as their production quantity. All 50 Onion dehydration Firms produced all that five items mention above and we consider their production in tons from 0 to 2000 tons \& more. 
We construct the following table 2 of Production done in financial Year 2019-2020. In this table we consider five items namely kibbled, chops, minced, granula and powder with their different quantity produced by Firms.

Table 2: Production of Dehydrate Onion Product by various Firms in Financial Year 2019-2020

\begin{tabular}{|c|c|c|c|c|c|c|c|c|c|c|c|}
\hline \multirow{3}{*}{ Sr.No } & \multirow{3}{*}{ Details } & \multicolumn{10}{|c|}{ Production in tons 2019-2020 } \\
\hline & & \multicolumn{2}{|c|}{ Kibbled } & \multicolumn{2}{|c|}{ Chops } & \multicolumn{2}{|c|}{ Minced } & \multicolumn{2}{|c|}{ Granula } & \multicolumn{2}{|c|}{ Powder } \\
\hline & & No. & \%tage & No. & $\%$ tage & No. & \%tage & No. & $\%$ tage & No. & $\%$ tage \\
\hline 1 & 0 to 100 tons & & & 21 & 42 & 25 & 50 & 29 & 58 & 24 & 48 \\
\hline 2 & 100 to 200 tons & & & 11 & 22 & 11 & 22 & 8 & 16 & 7 & 14 \\
\hline 3 & 200 to 400 tons & 11 & 22 & 13 & 26 & 9 & 18 & 9 & 18 & 12 & 24 \\
\hline 4 & 400 to 600 tons & 18 & 36 & 1 & 2 & 3 & 6 & 3 & 6 & 4 & 8 \\
\hline 5 & 600 to 800 tons & 10 & 20 & 1 & 2 & & & & & 1 & 2 \\
\hline 6 & 800 to 1000 tons & 3 & 6 & & & & & & & 1 & 2 \\
\hline 7 & 1000 to 1200 tons & 2 & 4 & 1 & 2 & 1 & 2 & & & & \\
\hline 8 & 1200 to 1400 tons & 1 & 2 & & & & & 1 & 2 & & \\
\hline 9 & 1400 to 1600 tons & & & 1 & 2 & 1 & 2 & & & & \\
\hline 10 & 1600 to 1800 tons & 1 & 2 & & & & & & & & \\
\hline 11 & 1800 to 2000 tons & 1 & 2 & 1 & 2 & & & & & 1 & 2 \\
\hline 12 & 2000 above & 3 & 6 & & & & & & & & \\
\hline & Total & 50 & 100 & 50 & 100 & 50 & 100 & 50 & 100 & 50 & 100 \\
\hline
\end{tabular}


Figure 3: Graphical Presentation of Dehydrate Onion Product by various Firms in Financial Year 2019-2020

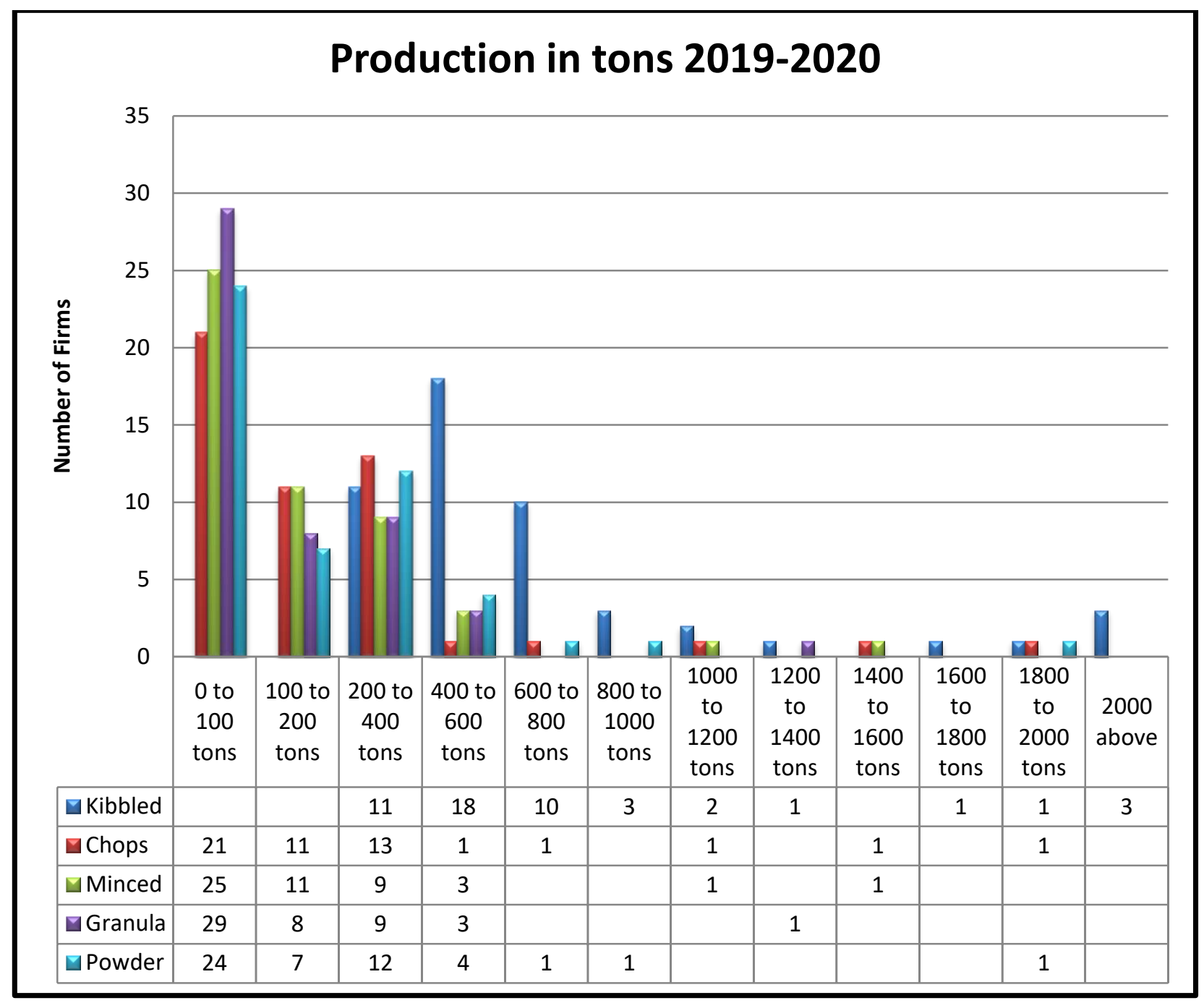

From the above figure 3 we can say that Maximum production of Kibbled is between 400 to 600 tons produced by 18 onion dehydration Firms, maximum production of Chops is between 0 to 100 tons produced by 21 onion dehydration Firms, maximum production of Minced is between 0 to 100 tons produced by 25 onion dehydration Firms, maximum production of Granula is between 0 to 100 tons produced by 29 onion dehydration Firms and maximum production of Kibbled is between 400 to 600 tons produced by 24 onion dehydration Firms in financial year 2019-2020.

\section{Reference:}

1) Meeta Punjabi, Aleen Mukherjee; supply chain for exports of dehydrated onions (A case study of Jain irrigation systems limited in India); FAO,2015

2) N. J. Ardeshna, S. B. Vekariya, R. L. Shiyani and V. L. Gondaliya (Dept. of Agricultural Economics, Junagadh, Gujarat) (2014, Economic Affairs); Economic assessment of onion dehydration in gujarat state: can it be a means for stabilizing onion prices?

3) Goudra Pramod Gouda, Ramachandra C T and Udaykumar Nidoni (Department of Processing and Food Engineering, College of Agricultural Engineeering Raichur) (Current 
Trends in Technology and Science ISSN: 2279-0535. Volume: 3, Issue: 3 (Apr-May. 2014)); Dehydration of Onions with Different Drying Methods

4) Jayeeta Mitra, Shanker Lal Shrivastva, Pavuluri Srinivasa Rao, IIT Kharagpur (2012) onion dehydration: a review; journal of food science and technology-mysore

5) Angles, S., Sundar, A., Chinnadurai, M. (2011), "Impact of Globalization on Production and Export of Turmeric in India - An Economic Analysis"

6) Serrano, Raúl., and Pinilla, Vicente (2010), "International Diversification And Performance In Agri-Food Firms" for time interval 1970-2012.

7) Akbari SH, Patel NC (2006) optimization of parameters for good quality dehydrated onion flakes. J Food sci techmol 43:603-606

8) PKumar (2006), performance of onion exports from India: A temporal analysis.

9) Mazza G. LeMaguer M(1980a) Dehydration of onions: some theoreyical and practical considerations. J Food Technol 15:181-194 